\title{
Model of Diversification of The Sasak Language Dialects:Understanding the Way Sasak Ancestors Migrated
}

\author{
Toni Samsul Hidayat; Husni Muaz; Nuriadi \\ Graduate Student of Mataram University, Indonesia
}

http://dx.doi.org/10.18415/ijmmu.v6i2.555

\begin{abstract}
The Sasak language is originally spoken by Sasak people in Lombok island. It has been identified to have five dialects. They are Kuto-kute dialect called Bayan Dialect (BD), Ngeto-ngete Dialect called Sembalun Dialect (SD), Ngeno-ngene dialect called Selaparang Dialect (SID), Meno-mene dialect called Pejanggik Dialect (PD), and Meriak-meriku dialect called Pujut Dialect (PjD). This research is aimed at identifying and establishing how the Sasak language dialects are diversified from the mother language. The answer may be used to understand the way Sasak language speakers migrated around the island. The method used is comparative synchronic method. Data are about 450 words including 200 basic words from Swadesh. They are collected through interview and library research. The collected data are analyzed comparatively under the Tree Model Theory proposed by August Schleicher to see the relation among the dialects. Result of the analysis shows that Sasak language dialects are diversified through internal subgrouping model, the second model of Tree Model Theory. There are three internal subgroups generating the five Sasak language dialects. The first is protoBayan-Sembalun (PBS) that diversifies Bayan Dialect (BD) and Sembalun Dialect (SD) and second protoSelaparang-Pejanggik-Pujut (PSPP) that diversifies Selaparang Dialect (SID) and protoPejanggik-Pujut (PPP). ProtoPejanggik-Pujut (PPP) then deversifies Pejanggik Dialect (PD) and Pujut Dialect (PjD). Model of the diversification of the Sasak language dialects reflects the way Sasak language speakers migrated from their first settlement around Bayan-Sembalun dialects area to other places around Sembalun and then moved to protoSelaparangPejanggik-Pujut dialect area and finally spread up into Selaparang dialect, Pejanggik dialect, and Pujut dialect area.Vertical analysis between the Sasak language dialects and protoAustronesian language, in case of lexical-phonological features, is in the line with the result of this research.
\end{abstract}

Keywords: Sasak; Language; Dialect; Comparative; Model; Diversification; Migration; Speakers

\section{Introduction}

Sasak language is spoken by not only Sasak people in Lombok but also by Sasak people living in some other islands, such in Sumbawa and Bali. In Lombok island Sasak is spoken by the majority population, both Sasak people and immigrants. According to BPS (Central Statistic Agency) data (http://ntb.bps.go.id), the population of Lombok island is about 3.352.988 people and most of them are Sasak that still use Sasak language as their daily lingua franca. 
Just like other language, Sasak also has some variants, which is popular called dialect, even sociolect. Dialect refers to subdivision of recognizably different type of language that does not, however, render intercommunication impossible or markedly difficult (Robin \& Crystal in Encyclopedia Britannica, Inc., 2017). In short, dialect is any variety of a language characterized by systematic differences in pronunciation, grammar, and vocabulary from other varieties of the same language (Meures, 2004). A brand of linguistics discipline discussing about dialect is called dialectology. While sociolect refers to the honorific forms used by the speaker of the language.

Sasak language is one of the ten biggest number of speakers of local languages in Indonesia. It has almost more than 3 millions speakers. Thus, study on it has been conducted since decades. Sasak dialect researches were firstly conducted by Teeuw (1951), Herusantoso, et al. (1987),Thoir , et al., (1986). The most recent research, on the same concern, was done by Mahsun (2006). According to those reseachers, except Mahsun (2006), Sasak dialects are divided into five.

They are Meno-mene dialect, Ngeno-ngene dialect, Ngeto-ngete dialect, Kuto-kute dialect, and Meriak-meriku dialect. Meno-mene is centrally spoken in Pejanggik (Central Lombok), West Lombok, Mataram, and a bit in East Lombok, Ngeno-ngene dialect is used by Sasak people in Selaparang, Ngetongete is used around Sembalun, Kuto-kute is in Bayan, and Meriak-meriku is used by people in southen part of central Lombok specifically in Pujut. The name of the dialects proposed by those researcher refer to the empire or kingdom of Sasak that had ruled Sasak island in the past.

This article is not about to discuss how many dialects of Sasak language has but to discuss how Sasak language diversifies its varieties, how Sasak language speakers migrated for the first time, and where they firstly settled. The last two objectives can be revealed through the result of the diversification model of the Sasak language dialects.

Data of this article were collected in the five Sasak dialects. The vocabulary gained from the five dialects were compared within the dialects and proto-Austronesian vocabularies reconstructed by Dempwolff (1938 in Dahl 1976 and in Ranabrata 1991). Austronesian vocabularies are used to see which dialect is closer to the Austronesian language. The result will be the basis of inferring the migration way. Besides, Sasak dictionary is also used to add and to complete them.

Result of the study is objected to answer two questions. The first is to answer the way Sasak language dialect are diversified and the second is how that model reveals the way Sasak ancestors migrated.

People migration and the language variation development have strong link. It is approved that the way people migrated can be learned from the variation of the language spoken by the people. Linguistic interralation among the variation of the language may reveal how and when the speakers of the language separated. Swadesh (in Mahsun, 1999) stated that basic words of a language changes $20 \%$ in a thousand years. Meaning that if a language variation has $20 \%$ differences in 200 basic words proposed by Swadesh with other variation, the language variation was born one thousand years a go. The less the differences, the younger the age of the variation. The more similarities they have, the closer they are. If the two or more variations are approved to be close, they are surely diversified from a single node. Number of the similarities and the differences among the variations reflect the way their speakers spreap up long time ago.

\section{a) Method}

This research aims to inverstigate and identify the model of Sasak language dialect diversification and patterns of the Sasak ancestors migrated in the past based on the model of the dialects diversification. 
Before going to do it, firstly, set of vocabularies in number of about 800 words consisting of basic words, body parts, cultural words, number, verbs, and adjectives is tabulized in data collection instrument. In the five dialects of Sasak language, data are collected using the instrument. In order to answer the questions of the research, the collected data are compared to identify the similarities and differences among the dialects. This is a compartive-descriptive research. The similarity and difference are used to group and to ungroup the dialects. The grouped dialect is usually bound by some inherited froms indicating that the member of the group is born from the same common mother. The making groups are used as the basis of establishing the model of the dialects diversification and that model is used, later, to identify the pattern of the Sasak ancestors migrated in the past. The final objective of the camparison is to model the Sasak language dialects diversificatioan and to pattern the way Sasak ancestor migrated in the past.

\section{b) Theoritical Concept}

The language tree theory or called Stammbaum theory was proposed by August Schleicher in 1853 in his article tittled Die ersten Spaltungen des Indogermanischen Urvolkes (Francois, 2013). The tree model presupposes an understanding of language diversification processes. To easly understand this theory, please look at the following figures.

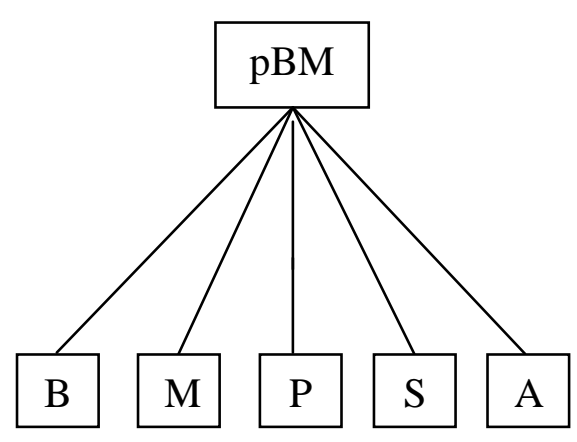

Figure 1-An unordered

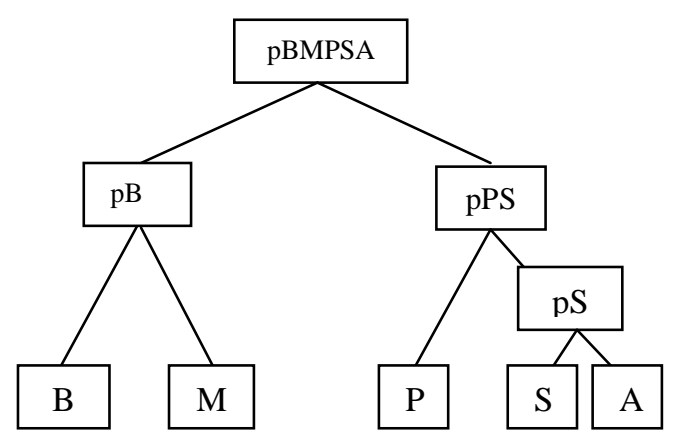

Figure 2-A Genealogical tree

All these two figures show that B, M, P, S, and A are genealogically related languages entails that they are ultimately descended from a common ancestor called proto-language, which in this case is called Proto-BMPSA. Figure 1 shows that each language is an independent descendant language of the protolanguage, which no claim about the family's internal structure. Such a flat tree may sometimes 
corresponds to specific historical situation, as when an ancestral society (speaker of the langaage) swiftly broke up into a number of separate subcommunities. Those are subcommunities B, M, P, S, and A, and quickly followed by a loss of mutual social (ofcourse including lingual) contact. Such situation might happen in the case of conflict or war where the subcommunity escaped and moved further a way from other subcommunity and from its mother community. While figure 2 captures a set of claims about internal structure of a language family. According to the figure, a claim is made that the languages B and $\mathrm{M}$ were subgrouped together in a subfamily named proto-language BM. It is by contrast with $\mathrm{P}, \mathrm{S}$, and A which were from their own subgroup called proto-PSA; a claim is made that $\mathrm{S}$ and A formed a subgroup of their own a part from A. Following the nested pattern, the language $S$ is said to belong to the SA subgroup, which in turn form a branch of a larger subgroup, proto-PSA family.

Based on the data and the research conductued by any researcher in all over the world, figure 2 is claimed to be the most common way in descending language. While figure 1 seems to happen in a certain language diversification and in a certain situation, such as migration of Javanese speakers from Java to Suriname. Figure 1 is associated as flat tree that may corresponds to a certain historical situation. The example of this is the descending process of Proto-Oceanic into lewer-level subgroups. Another closer example from Mbete (1990) is Proto-Balinese-Sasak-Sumbawa (PBSS) subgrouping process. According to Dyen (1957) and Esster (1937), PBSS is split up through flat tree as illustrated below.

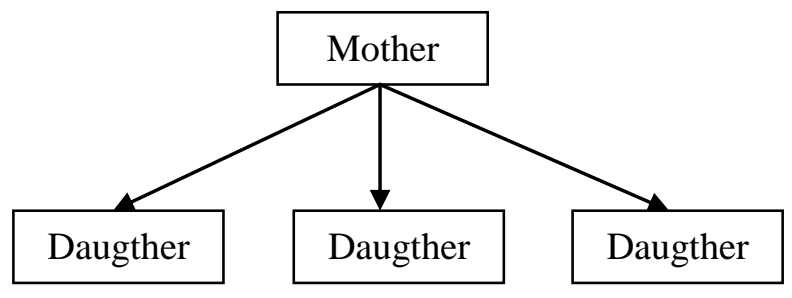

Figure 6: Flat model/an unordered genealogical

In 1990, Mbete for his dissertation conducted a study on Balinese, Sasak, and Sumbawa languages. What he found was quite different from other researchers above. His findings is illustrated below.

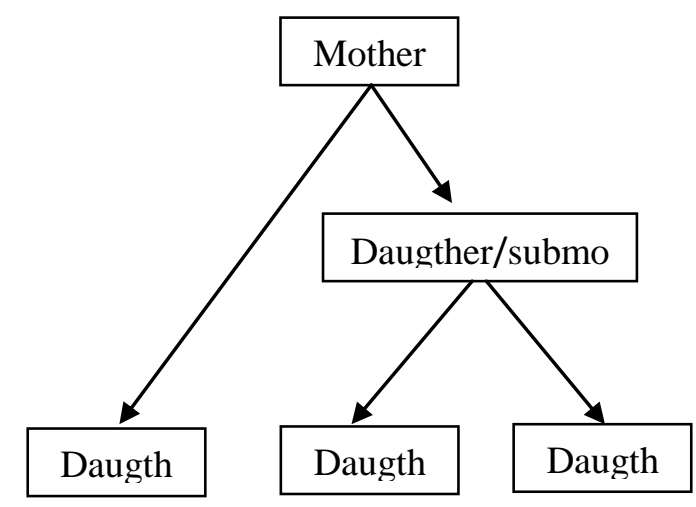

Figure 7: Internal subgroubing

He found that Sasak and Sumbawa languages are closer as they shared some exclusive innovations together in which the concerned innovations are not occurred in Balinese. This phenomenon 
led to a conclusion that Sasak and Sumbawa had a mother language (intermediate family) that paralleled to Balinese language. Meaning that PBSS split up into two dialects, named Balinese and Proto-SasakSumbawa (PSS). Later PSS broke up into Sasak and Sumbawa dialects and now become Sasak language and Sumbawa language.

\section{Discussion}

Historical inference may become very powerful when independent lines of evidence can be integrated into a coherent account. One of the independence lines that can support the historical inference is linguistic evidence. Linguistics evidence is believed to be a recording data that can be used to reveal the history of the speakers. There are a lot of linguistics evidences containing history, for example the distribution of showa sound $(\partial)$ in Sasak language in penultima and ultima position. The emergence of

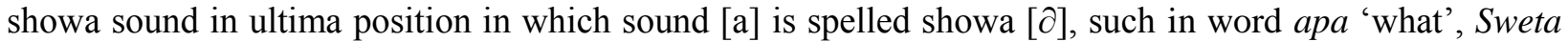

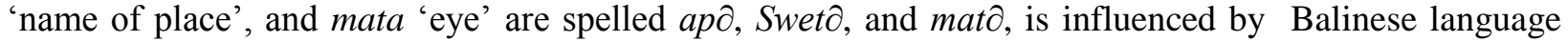
that was brought by Blinese people who colonized Lombok for more that 150 years. It is not just a symbol, it reflects the role of Balinese power toward the development of Sasak civilization in the past. This showa sound in ultima position is not distributed evenly in all Sasak dialects which means that, at the time, Balinese did not rule the entire place of Lombok island (the homeland of Sasak language). Another examples, the lexemes of tang, obeng, heler, kapling, absensi, and karakter are some of the loanwords from Dutch, bangku, Belanda, beranda, bola, and bolu are some of the loanwoards from Portuguese which mean that there were intensive contacts happened between Nusantara people and Dutch and Portuguese in the past. Suriname language spoken in Suriname has a lot of similarities with Java language spoken in Java island. After doing research on it, it is found that people of Suriname were mostly from Java who migrated during the Dutch colonization era. These all examples show the important role of linguistics in helping historical experts making their conclusions.

The history of Sasak people, the speakers of the Sasak language, is still dark since it has no conclusive evidence, ruins, and written document concerning their civilization before year of 1000 . Therefore, revealing the history of Sasak may lead to a controversial and debate findings. Putting into account, the linguistics evidence in revealing the history of Sasak is considered to be a new concept and approach. Such approach is not a really new one. It had been used by another scientists since decades, even hundreds of years. Let's quote Darwin's statement saying that language evolution and human history have a very strong link (Atkinson and Greenhill, 2011).

In accordance with it, this study is trying to reveal a correlation between language variation diversifiation model and the way speakers of the language migrated in the past. The tittle of the study reflects that before coming to a conclusion about the way Sasak people migrated in the past, model of the Sasak language dialects diversification shall be made first. The diversification model is used as a basis of making a model or map of how Sasak people migrated. Both models are underpin by recent linguistics evidences.

The Sasak language variation so called dialects are taken from the name and the number of them proposed by Thoir et.all (1982: 22-24). The names are taken from a term meaning 'that way (begitu), this way (begini)'. The term begini-begitu 'that way-this way' in each dialect is realized differently. In Bayan dialect it is realized kuto-kute, in Sembalun dialect it is realized ngeto-ngete, in Selaparang dialect it is realized ngeno-ngene, in Pejanggik dialect it is realized meno-mene, and in Pujut dialect it is realized meriak-meriku. They are some other names used to name the Sasak language daielcts, such as names proposed by Mahsun (2006). In this study, the researcher has chosen Thoir et. all proposal under a consideration that the names can reflect language change phenomenom naturally. Look at how sound /k/

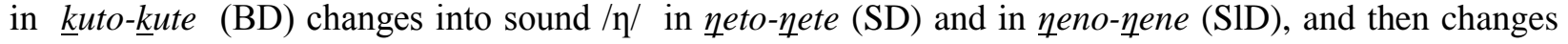


into $/ \mathrm{m} /$ in meno-mene and in meriak-meriku (PjD) and also at how sound $/ \mathrm{t} /$ in kuto-kute (BD) and in

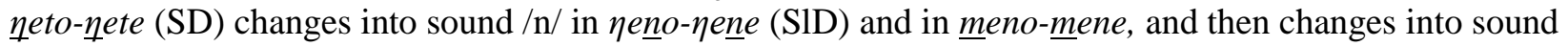
$/ \mathrm{k} /$ in meriak-meriku $(\mathrm{PjD})$. Through this changes we can make the following rules.
a. kuto-kute $\rightarrow$ ngeto-ngete $\rightarrow$ ngeno-ngene $\rightarrow$ meno-mene $\rightarrow$ meriak-meriku
b. $\mathrm{k} \rightarrow \eta \rightarrow \mathrm{m} / \#-\quad$ : sound $/ \mathrm{k} /$ changes to $/ \mathrm{\eta} /$ and then to $/ \mathrm{m} /$ in the first position of the word.
c. $\mathrm{t} \rightarrow \mathrm{n} / \mathrm{-v} \# \quad:$ sound $/ \mathrm{t} /$ changes to $/ \mathrm{n} /$ in the position before the last vowel of the word.
d. $u \rightarrow \partial / \# c-\quad:$ sound $/ \mathrm{u} /$ changes to $/ \partial /$ in the position after the first consonant of the word.

The changes happened regularly and this may reflect the way the speakers of the dialects moved from one place to another. To support this assumtion, other linguistics evidences will be elaborated below.

\section{a) Model of Diversification}

As it has drawn up in the theory that there are two types of diversification model. The first is flat model and the second one is internal subgrouping model. In the flat model, all variations or daugther languages are diversified directly from the mother language and no intermediate node grouping two or more variations. While, in internal subgrouping model, daugthers are diversified through one or more intermediate nodes becoming another submother that descends two or more subdaugthers. Due to the analysis of hundred of lexemes in the five Sasak language dialects, it is found that the model of diversification used in descending the five dialects is internal subgrouping model. The model is made under linguistics evidences and here is the model.

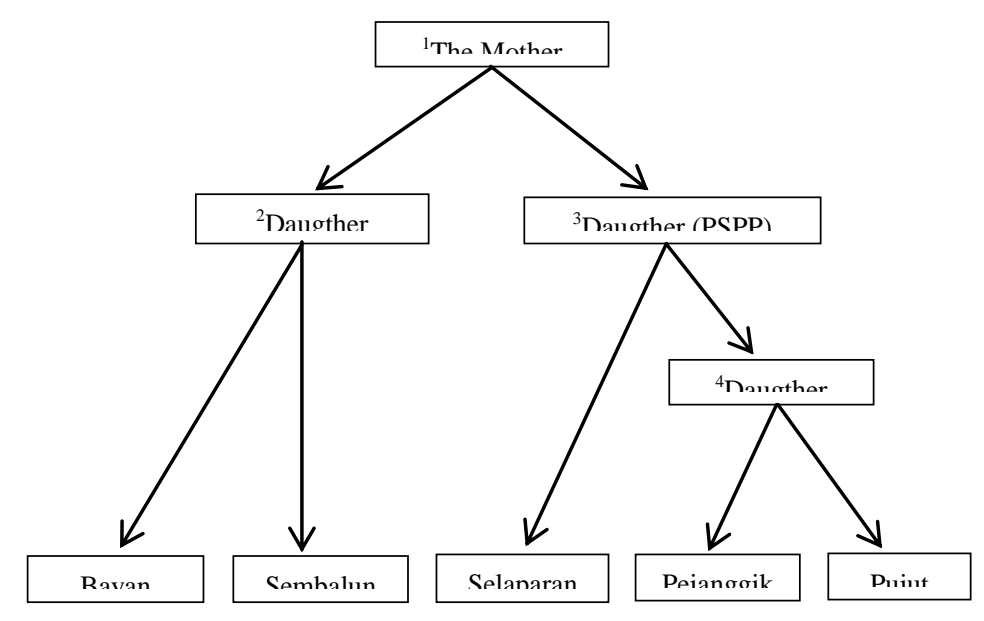

Figure 8: The diversifaction model of the Sasak

This model is internal subgrouping model, the second model of language diversification proposed by August Schleicher in his Tree Model Theory. The model above shows that the Sasak language mother (SLM), number 1, firstly descended two intermidiate nodes (daugthers) which is linguistically named Proto-Bayan-Sembalun (PBS). This daugther (PBS) later descends two recent dialects which we know now as Bayan and Sembalun dialects. To know that Bayan and Sembalun dialects are born from the same 
common mother, it can be seen from the similarities they have sinchronically now, both lexically and phonologically. Both similarities are considered to be the inherited forms that they recieved from thier mother language (protoBayan-Sembalun: the first intermediate node). These forms are descended by the mother to its daugthers and hence these forms are still maintained by the daugthers (Bayan and Sembalun dialects). Some of them ofcourse gradually change as consequence of internal changes and contacts with others. Determination of the lexical similarities is done through looking at the realization of some given glosses that have the same meaning and forms. The forms with the same meaning of those glosses are realized differently by the other dialects. Meaning, those similarities are only familiar in those two dialects and have grouped Bayan and Sembalun then sparated them from other dialects.

There are at least 97 lexemes that group Bayan and Sembalun dialects and separate them from Selaparang-Pejanggik-Pujut dialects. This indicates that Bayan and Sembalun are dialects of an upper past dialect named protoBayan-Sembalun (PBS). It is named protoBayan-Sembalun (PBS) as no one knows what it looked exactly like and what its name was and no written document indicating its name. While today, language variation that is spoken in Bayan is named Base Bayan and that tradional name is very popular among speakers of other Sasak language variation speakers, while linguists name it Bayan dialect as it is spoken centrally in Bayan and around. Both of the names are put and written down in some modern documents which can be later used by future scientist to study this dialect. In some local content references, base Bayan or base Daye is used to name Bayan dialect. The same happens in naming the other dialects in which basei 'language' is used to indicate the variation and the place where it is spoken is mentioned along with the word. Therefore there are base timuq (east) referred to Selaparang dialect (in East Lombok), base tengaq (central) referred to Pejanggik dialect (in Central Lombok), and base Pujut referred to Pujut dialect located in Pujut. Those almost hundred of inherited words are also becoming evidence of intermediate node two which is drawn up by mother number three. This intermediate node descended Selaparang dialect and mother of Pejanggik and Pujut dialect (mother number four) which we call here ProtoPejanggik-Pujut. The node is underpin by the same lexical similarities realized by Selaparang, Pejanggik, and Pujut dialects.

The last diversifiaction process was done by PPPj and it now becomes two dialects called Pejanggik Dialect (PD) and Pujut Dialect (PjD). The names of the dialects refer to the centre area or the district area where the dialects are spoken today. Those names also reflect the kingdoms history in which they settled and ruled those areas. This last diversification process is labelled by intermediate node three which is known by mother number three. This conclusion is made under some of the lexical and phonological similarities that both dialects share together. They are considered to be the inherited words recieved from the same common mother.

There are at least twenty five inherited words indicating that SID and PPPjD are separated and indicate that Pejanggik and Pujut dialects have upper node uniting them. Besides having these ten lexical evidences, the relation between $\mathrm{PD}$ and $\mathrm{PjD}$ are also found in the use of clitics. From the use of clitics we can infer that Selaparang and Pejanggik-Pujut dialects are put in different group. Selaparang has unique forms which are different very much with Pejanggik-Pujut dialect, especially in the use of clitics -meq (you male) and -bi (you female). Since these clitics are used by both dialects, it may be inferred that the clitics are derived from their protodialect (mother). Meaning that the clitics were used by their protomother and then descended the clitics to its dauthers, in this case, to Pejanggik and Pujut dialects. To see where the clitics firstly came from and how their protoforms looked like, we need to invent all clitics used in the whole dialects and draw up their changes. 


\section{b) Sasak Language Dialects}

As it is stated previously that Sasak has five dialects at the present time. The dialects are distributed around the Lombok island and the areas where the dialects are spoken are drawn up in the following map.

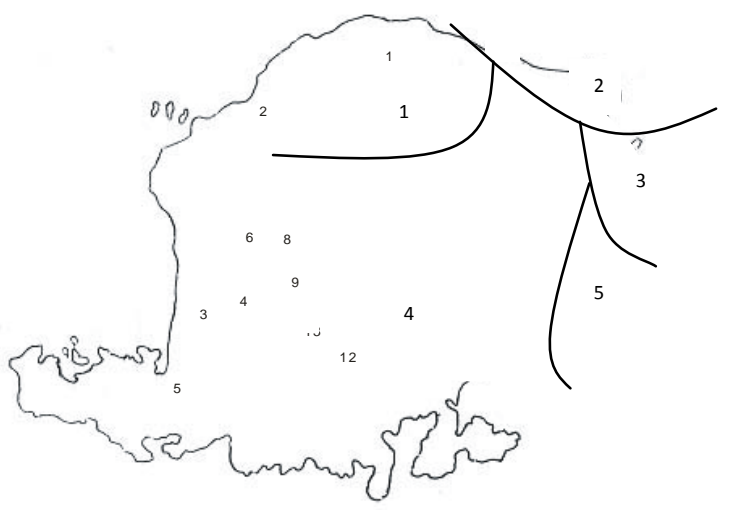

Note:

1. Kuto-kute dialect (Bayan)

2. Ngeto-ngete dialect (Sembalun)

3. Ngeno-ngene dialect (Selaparang)

4. Meno-mene dialect (Pejanggik)

\section{Meriak-meriku dialect (Pujut)}

This map of Lombok Island contains some lines showing the location where the five dialects are centered and spoken and their distributions. The lines are imaginary lines used to border the approximate areas where the variations are spoken. Number 1 is Bayan Dialect (BD), number 2 is Sembalun Dialect (SD), number 3 is Selaparang Dialect (SID), number 4 is Pejanggik Dialect (PD), and number 5 is Pujut Dialect $(\mathrm{PjD})$. If we eloborate the places based on the map above, where the dialects are spoken, the following are the name of the places where they are spoken.

\section{c) Model of Migration}

Result of the linguistics analysis concluding the diversification model of the Sasak language dialects as drawn up above also leads us to a hypothesis of the way Sasak people migrated for the firts time. The following two maps present that migration 


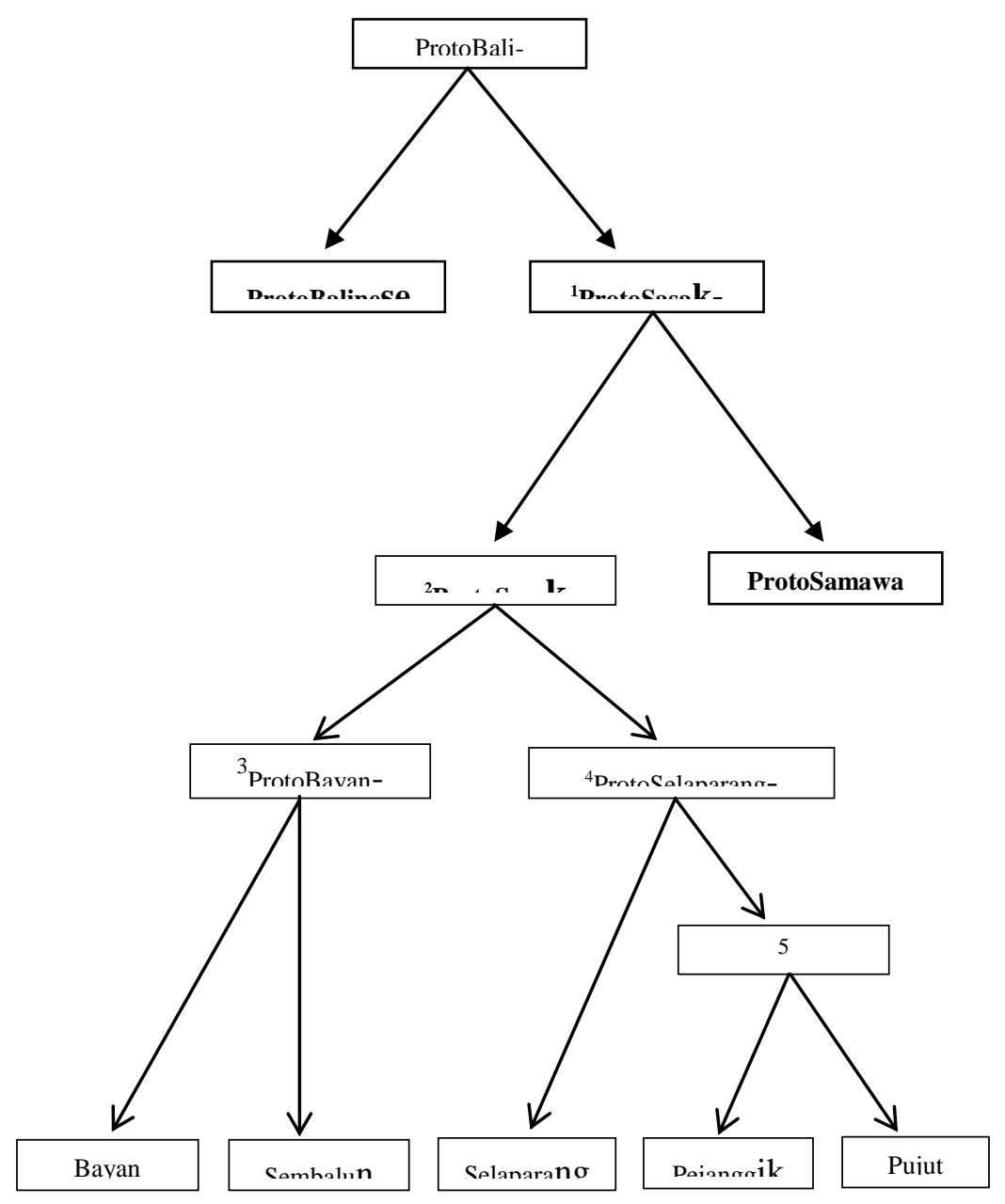

Figure 12: The way Sasak language and its dialects are

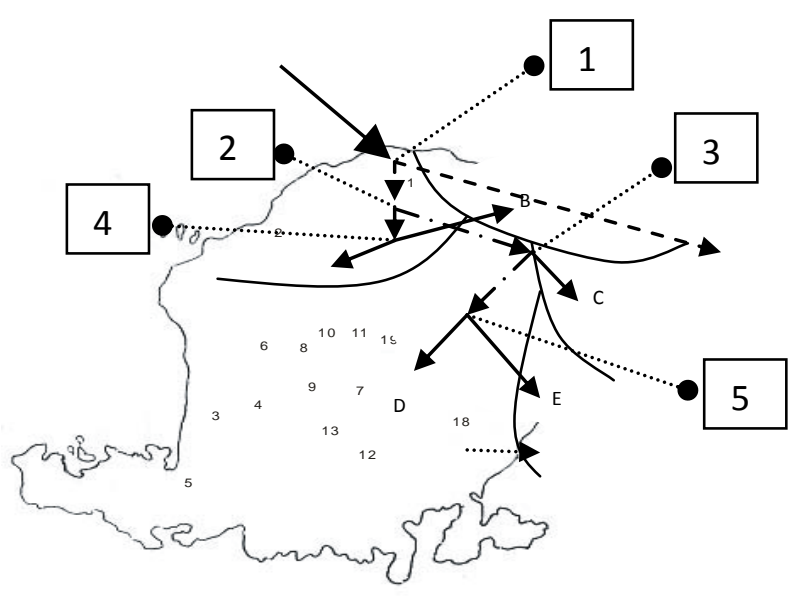

Notes:

- Alphabet 

A: Kuto-kute dialect (Bayan)
B: Ngeto-ngete dialect (Sembalun)
C: Ngeno-ngene dialect (Selaparang)
D: Meno-mene dialect (Pejanggik)
E. Meriak-meriku dialect (Pujut)

\section{- Number}

1. Node 1 indicating approximately where Austronesian people (the speakers of Sasak speakers) firstly landed and settled in Lombok Island. This node is infered from Mbete (1990) and the comparison between current features of Sasak language dialect spoken in Bayan and Sembalun with the feature of Austronesian language features and Samawa language features.

2. Node 2 indicating approximately where Sasak language speakers settled after splitting up with the other group of speakers going to Samawa island. This group is the mother of Sasak people before they split up into Bayan-Sembalun people and Selaparang-Pejanggik-Pujut people.

3. Node 3 indicating approximately where a group of Sasak language speakers settled before they split up into Bayan people and Sembalun people.

4. Node 4 indicating approximately where a group of Sasak language speakers settled before they became Selaparang people and Pejanggik-Pujut people.

5. Node 5 indicating approximately where a group of Sasak language speakers settled before they became Pejanggik people and Pujut people.

The following map ilustrates the routes that Sasak people used to move from one place to another.

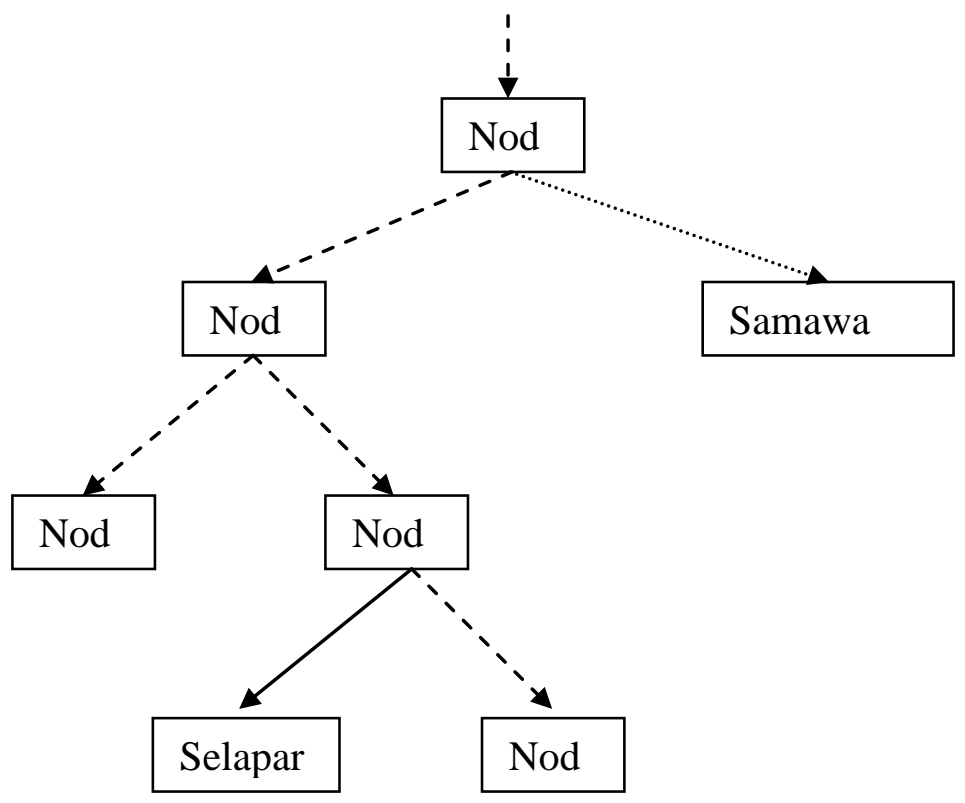

Note: $\quad$ Figure 13: The way (routes) Sasak speakers migration

Node 1: Austronesian people landed

Node 2: A group of people called Sasak is emerged 
Node 3: A subgroup of the people, parents of Bayan and Sembalun people

Node 4: A subgroup of people, parents of Selaparang, Pejanggikm and Pujut people

Node 5: A subgroup of people, parents of Pejanggik and Pujut people

If we may describe the map, it says that Austronesian people came to Lombok and landed for the first time in a certain part of Bayan-Sembalun Dialect area (indicated by arrow number 1). Not long enough from where they firstly landed, they split up into two groups. One group stayed around and the second group migrated to Sumbawa Island (indicated by the dash line). The way they moved to Sumbawa island is still not yet verified as it has not been found the physical evidences to support this linguistics finding. Whether they migrated across the Lombok island and crossed the sea in east or directly across the sea from north to Sumbawa island is still undiscovered. This hypothesis can be seen from the semilarities between Bayan-Sembalun Dialect and Samawa language, such apa 'what', lima 'five', baca 'read', pira 'how many' in Bayan-Sembalun dialect are realized the same in Samawa language. The most prominent evidence is that both Bayan-Sembalun dialect and Samawa language still maintain sound/vowel /a/ positioned at end of the word that was generated from Austronesian language. In other Sasak language

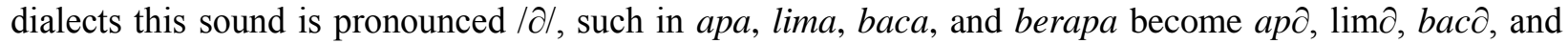
pirz. Besides having the same phonological appearance, Bayan-Sembalun dialect and Samawa language also have lexical similarities as drawn up in the examples above and other Sasak dialects ofcourse realize

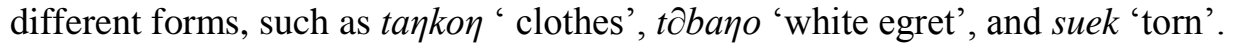

The first group of Austronesian people who had landed and stayed around (drawn by the second dash line indicated by arrow number 2) later split up into two communities. The first community is the mother of Bayan-Sembalun speakers (indicated by arrow number 3) and the second one is the mother of Selaparang-Pejanggik-Pujut speakers as indicated by arrow number 4. Linguistics evidences that support this hypothesis have been discussed above, both evidences relating Bayan-Sembalun and relating Selaparang-Pejanggik-Pujut. Group of Selaparang-Pejanggik-Pujut speakers as indicated by arrow number 4 later split up also into two communities. They are Selaparang dialect speakers community and community that spoke protoPejanggik-Pujut dialect as indicated by arrow number 5 . Finally once upon a time, Pejanggik-Pujut speakers community then split up into Pejanggik dialect speakers community and Pujut dialect speakers community, as drawn up by $\mathrm{D}$ and $\mathrm{E}$.

The emerge of the hypothesis saying that Austronesian people, the ancestor of Sasak and Samawa people, came to Lombok island and landed around the north coast line where Bayan and Sembalun dialects are spoken, before spreading up around the island and to Sumbawa island is underpin by Mbete findings and the comparison between Sasak dialects and Austronesian vocabularies. Some data that underpin this hypothesis are *mata 'eye', *lima 'five', *sawa 'wife', *apa 'what', and *ina 'mother' in Austronesian language are realized the same in Bayan-Sembalun dialect.

There are a lot of other similarities found between Bayan-Sembalun dialect and Austronesian. Other Sasak dialects also still reflect the phonemes and the lexemes of Austronesian forms, but the most important form that Bayan-Sembalun dialect has until it is assumed to be very close to the Austronesian form is it still maintain the sound /a/ at the end of all the words ending with it. While other dialects use / $\partial /$ instead of it. Samawa language spoken by Samawa people in Sumbawa island still also maintains the sound as Bayan-Sembalun does.

Hypothesis saying that Sasak ancestor firstly landed and settled around the north cost and spread up through Sembalun toward Selaparang dialect area can be underpin by some data such as jurang 'gap', mengalir 'flow', bengkak 'puffy', bunuh 'kill', and daging 'meat' are realized juran, nelek, baq, mateq, and mpaq by Bayan, Selaparang, Pejanggik, and Pujut dialects, while Bayan dialect itself realized them differently. These all data indicate that Sembalun is the starting point moving forward to Selaparang 
dialect area and showing that Sembalun people and Selaparang-Pejanggik-Pujut people have the same ancestor.

\section{Conclusion}

In this subchapter, the researcher would like to convey the answers of the two research questions.

\section{a. The Sasak Language Dialects Diversification Model}

Finding of this research shows that the model of the Sasak language dialect diversification is Internal Subgrouping Model, the second model in tree model theory. The findings that support this result are gained from hundreds of lexical evidences underpinning grouping and ungrouping the dialects in three major intermediate nodes. Each node is a group consisting of two or three dialects made under the basis of phonological and lexical similarities.

(1) Intermediate Node 1 indicating that Kuto-Kute dialect or Bayan dialect and Ngeto-ngete dialect or Sembalun dialect are descended from one upper dialect named Proto-Bayan-Sembalun dialect. This node is underpin by lexical and phonological evidences drawn in table 6

(2) Intermediate Node 2 indicating that Ngeno-ngene dialect or Selaparang dialect, Meno-mene dialect or Pejanggik dialect, and Meriaq-meriku dialect or Pujut dialect are descended from the same common mother dialect named Proto-Selaparang-Pejanggik-Pujut dialect. This node is underpin by lexical and phonological evidences drawn in table 7

(3) Intermediate Node 3 indicating that Menu-mene dialect or Pejanggik dialect and Meriak-meriku dialect or Pujut dialect are descended from the same upper dialect called Proto-Pejanggik-Pujut dialect. This is based on number of inherited forms found in these two dialects as drawn up in table 8 .

b. Model of Sasak Language Speakers Migration

The pattern of how Sasak language speakers migrated is made under the basis of the model of Sasak language dialects diversified. There are at least five nodes indicating where the speakers settled before they spread up around the areas.

(1) Node 1 indicating approximately where Austronesian people (the speakers of Sasak speakers) firstly landed and settled in Lombok Island. This node is infered from Mbete (1990) and the comparison between current features of Sasak language dialect spoken in Bayan and Sembalun with the feature of Austronesian language features and Samawa language features.

(2) Node 2 indicating approximately where Sasak language speakers settled after splitting up with the other group of speakers going to Samawa island. This group is the mother of Sasak people before they split up into Bayan-Sembalun people and Selaparang-Pejanggik-Pujut people.

(3) Node 3 indicating approximately where a group of Sasak language speakers settled before they split up into Bayan people and Sembalun people.

(4) Node 4 indicating approximately where a group of Sasak language speakers settled before they became Selaparang people and Pejanggik-Pujut people. 
(5) Node 5 indicating approximately where a group of Sasak language speakers settled before they became Pejanggik people and Pujut people.

\section{References}

Azhar, Muhammad, (1997). Kamus Bausastra: Sasak-Indonesia, Indonesia-Sasak. PT. Intan Pariwara. Klaten, Jawa Tengah.

Aitchison, J., 1993. Linguistics. Hodder\&Stoughton: London.

Dahl, Otto Christian, (1976). Proto-Austronesian: Second Revised Edition. Studentliteratur. Curzon Press.

Mahsun. (2006).’Kajian Dialektologi Diakronis Bahasa Sasak di Pulau Lombok". Yogyakarta: Gama Media.

---------. (1995). “Dialektologi Diakronis: Sebuah Pengantar”. Yogyakarta: Gajdah Mada University Press.

Thoir, Nazir, et al. (1986) "Tata Bahasa Bahasa Sasak”. Denpasar. Research Project on Indonesian and Regional Language and Literature. Departement Pendidikan dan Kebudayaan Republik Indonesia.

Ranabrata, Utjen Djusen. (1991). Refleks Fonem Proto-Austronesia Bahasa Sunda. Jakarta. Departemen Pendidikan dan Kebudayaan Republik Indonesia.

Mbete, (1990). Refleks Proto-Austronesia dalam Bahasa Bali, Sasak, dan Sumbawa. Udayana University.

Ross, M. (2006). Language Family and Linguistic Diversity. The Australian National University. Elsevier Ltd.

Whinney, Mac Brain. (2005). "Language Evolution and Human Development". New York: Guilford Press, Cambrigde University Website. "The Origin of The Language".Atkinson and Greenhill. (2011). "Language Evolution and Human History". Philos Trans R Soc Lond B Biol Sci. 2011 Apr

\section{Copyrights}

Copyright for this article is retained by the author(s), with first publication rights granted to the journal.

This is an open-access article distributed under the terms and conditions of the Creative Commons Attribution license (http://creativecommons.org/licenses/by/4.0/). 